\title{
Türk Eğitim Sistemindeki Kozmik Yapının Felsefesi ${ }^{1}$
}

\begin{tabular}{lccc}
\hline MAKALE TÜRÜ & Başvuru Tarihi & Kabul Tarihi & Yayım Tarihi \\
Derleme Makalesi & 20.04 .2020 & 24.04 .2021 & 31.05 .2021 \\
\hline
\end{tabular}

\author{
Nuray Özge Sağbaş \\ Milli Eğitim Bakanlı̆̆ 1 \\ Murat Özdemir iD
Hacettepe Üniversitesi
}

Öz

Bu çalışmanın amacı, Türk eğitim sisteminin yapısını etkileyen ve bu yapıya yön veren kavram, ilke ve düşünce sistemlerini tarihsel gelişim süreci içinde betimlemektir. Bu amaçla skolastik dönem, modernizm ve postmodernizm süreçleri kapsamında bilgi üreten düşünürlerin kuramları ve bu kuramların felsefi yönünün Türk eğitim sistemine yansımaları incelenmiștir. $\mathrm{Bu}$ amaçla skolastik, modernizm ve postmodernizm dönemlerinde etkili olan düşünürler, fikirleri ve söz konusu dönem içinde geçerli olan felsefi yapıların eğitim sistemini nasıl şekillendirdiği kozmik yapı kavramı kullanılarak anlatılmıştır. Bunun için de öncelikli olarak dönemler içinde yer alan düşünürlerin savunduğu felsefi görüşler, bu felsefi görüşlerin hangi akıma yön verdikleri ve nihayetinde ülkemizdeki eğitim sistemindeki gelişmelere yer verilmiştir. Skolastik dönem, döneme damgasını vuran teolojik dünya görüşü; modernizm ekonomik, kültürel ve siyasal değişimlerin sosyal yapıda meydana getirdiği değişimler; postmodernizm ise küreselleşme sürecinin etkisi altındaki öteki olanı anlama çabası altında eğitim felsefesine damgasını vuran akımlar temelinde çalıșılmıştır. Bu çalışma başlıkları altında batıda esmeye başlayan kozmik yapı rüzgarının ülkemizdeki eğitim felsefesi ve akımlarını etkisi altına aldığı ve şekillendirdiği sonucuna ulaşılmıştır.

Anahtar sözcükler: Skolastik felsefe, modernizm, postmodernizm, eğitim felsefesi akımları.

Etik kurul kararı: Bu araştırma, derleme makalesi türünde olduğu için etik kurul kararı zorunluluğu taşımamaktadır.

${ }^{1} 6$. Uluslararası Kaos, Karmaşıklık ve Liderlik Sempozyumunda bildiri olarak sunulmustur.

${ }^{2}$ Sorumlu Yazar: Dr., Özel Kalem Müdürlüğü, E-posta: nurayozgesagbas@hotmail.com, https://orcid.org/0000-0003-2630-8620

${ }^{3}$ Prof. Dr., Eğitim Fakültesi, Eğitim Bilimleri Bölümü, Eğitim Yönetimi Anabilim Dalı, E-posta: mrtozdem@gmail.com, https://orcid.org/0000-0002-1166-6831 
Eğitim yönetimine yön veren felsefi akımlar, tarih felsefesi kapsamında değerlendirildiğinde dünya ve Türkiye tarihine üst perdeden bir bakışı, diğer yönden insanoğlunun felsefi açıdan geçmiş üretimlerinin geleceğe nasıl köprü oluşturduğunu çalışmayı gerektirir (Macit ve İplikci, 2017). Ortaçağ felsefesi olarak da adlandırılan skolastik düşünce, dinsel öğretilerin dünyaya ilişkin görüşlerine ve hakim felsefe anlayışına temel oluşturmuştur. Bu dönemde felsefi çalışmalar, kilisenin ilke ve kuramları doğrultusunda ruh bulmuş ve durağan bir dönem geçirmiştir. Geleneksel toplum yaşamından kendi kabuğunu kırarak sıyrılan modernizm, aydınlanma hareketi olarak adlandırılan ve İtalya' da başlayarak Avrupa'yı etkisi altına alan edebiyat, güzel sanatlar ve bilimsel alandaki yenilikleri kapsayan Rönesans, Martin Luther'in kilisenin din anlayışına karşı çıkarak ürettiği fikirlerle hızla yayılmasına katkıda bulunduğu Reform hareketini kapsar. Aydınlanma felsefesi, bir süre sonra yerini yeni ulus devletlerinin kurulmasına ve aklın yeniden merkeze alınmasına katkı sağlayan Fransız Devrimi'ne bırakmış ise de Fransız Devrimi ile eş zamanlı olarak başlayan Sanayi Devrimi daha uzun soluklu bir dönemi içine almıştır (Kırılmaz ve Ayparçası, 2016). 1950'li yıllardan itibaren Amerika Birleşik Devletleri'nde etkisini göstermeye başlayan postmodernizm, modernizm sürecinden kopuşu ve modernizmin ötesine geçişin bir ifadesi olarak alanyazında yerini bulmuş ve modernizm sürecinde eksik kalan yeni ifade biçimlerini işlemeyi esas alarak netliğe karşı kuşkuculukla yaklaşmıştır (Şaylan, 2016).

Skolastik felsefe dönemi 8. yüzyıldan 15. yüzyıla kadar olan dönemi kapsayan teolojik temele dayalı fikirler sunulduğu, bu fikirlerin Hristiyan, İslam ve Yahudi inanç sistemleri üzerinde yükseldiği; Farabi, İbn-i Sina, İbn-i Rüşd, Aquinolu Thomas, Roger Bacon, John Duns Scotus bu döneme ilişkin fikirlerini Antik Çağ felsefesine özellikle de Aristoteles felsefesine dayandırdıkları dönemdir. Skolastik dönem, eğitim-öğretim amaçlı çalışmaların yapıldığı ve gerçeğin belli bir düzen içinde verilmesi gerektiği inancına dayandırılmıştır (Cevizci, 2001). Bu dönemde Batı'da dini öğretiler, tartışma ve takrir yoluyla öğretilip akıl yoluyla doğrulanmaya çalışılmıştır. Ortaçağ Asya devletlerinde ise eğitimde dinsel amaç etkili olmakla birlikte skolastik dönemin eğitim anlayışından dini öğretileri doğrulama çabası yönüyle ayrılmaktadır. Yine Orta Asya devletlerinde skolastik yöntem adı verilen düşünce sisteminin hukuk bilimi için geliştirilmiş olduğu inancı yaygın olmuştur. Osmanlı Devleti ise, İslam ve Türk medeniyetlerinden gelen eğitim anlayışını sıbyan mektepleri, medreseler, Enderun mektebi, tekke ve zaviyeler ile sergilemiştir (Gümüş, 2010).

Moderniteye geçildiğinde ise akıl, bütün toplumsal yapıya egemen olmuştur. $\mathrm{Bu}$ dönem dinin, toplumdaki mutsuzluğun asıl nedeni olduğunu ve eski olana karşı çıkılarak yeni olanın inşa edilmesi gerektiği üzerinde durur (Macit ve İplikci, 2017). Modernite, aydınlanma felsefesi ile gelişen bir dönemdir (Aydın, 2006). Rönesans ile birlikte insan ve doğanın araştırılması gerektiğine ilişkin inanç ortaya çıkmış ve Copernicus'un görüşleri bu dönemde kilise ile bilim arasındaki mücadelede ilham kaynağı olmuștur (Köroğlu ve Köroğlu, 2016). Aydınlanma çağı ise 1688 yılında 
İngiliz Devrimi ile başlayan ve 1789 Fransız Devrimi ile en ihtişamlı dönemini yaşayan düşünce hareketine verilen isimdir. Akla, bilime, bilgideki nesnelliğe vurgu yapar. Bu dönemde Locke, Hume, Bacon, Newton, Kant, Rousseau bu dönemin önde gelen isimleridir (Çüçen, 2006). Osmanlı Devleti eğitim sisteminde Rönesans, Reform hareketleri ve coğrafi keşifler sonucunda duraklama dönemine girilmiş, bu durumdan kurtuluşun kaynağı olarak Batının eğitim tekniklerini görmüş ve Batılılaşma hareketi 18. yüzyılda etkisini hissettirmiştir (Karataş, 2003).

Postmodernizm ise 1950'li yıllarda modernizme tepki olarak ortaya çıkmışsa da ülkemizde 1990'lı yıllarda tartışılmaya başlanmıştır. Küreselleşme, bilginin öznelliği, çok kültürlülük, yorumsamacı paradigmanın egemen olduğu postmodernizm ile gündeme gelen önemli bir kavramdır. Küreselleşme ile toplumlar, farklı toplumlarda meydana gelen değişikliklerden etkilenmekte ve merkezde birleşme yoluna gitmektedirler (Kılıç ve Bayram, 2014). Foucault, Nietzsche, Dewey, Kuhn, Feyerabend ve Habermas postmodernizm dönemi ile ilişkilendirilen önemli düşünürlerdir (Aydın, 2006). Postmodernizmin ülkemiz eğitim sistemine etkileri, eğitim örgütlerinde insana verilen önem ve yönetim başlıklarında kendini göstermiştir (Özdemir, 2014).

Eğitimdeki felsefi akımlar, eğitim sistemindeki politikaları etkileyerek gerçekleştirilmek istenen eğitimsel amaç ve hedeflere yön vermiştir. Kimi zaman öğretmen ve konu merkezli olan yaklaşımlar, son yıllarda ulusal ve uluslararası alanda yapılan sınavlarda kendini başarısızlık olarak göstermiş, öğrenci merkezli eğitime yer verilmesi gerektiğine ilişkin bir oluşum içine girilmiştir. Yeniden yapılanma sürecini ve postmodernizmin etkilerini de içine alan bu felsefi akımların temeli ise Antik Çağ'a, Yunan felsefesine dayanmaktadır. Geleceğe yön veren yapıyı anlamak geçmişi anlamaktan geçer. Geçmiş, geçip biteni belirtir. Ancak bıraktığ i izlenimler ve deneyimler sayesinde geleceğe rehberlik eder, yön verir. Geçmişin rehberliği ne kadar güçlü olursa var olan zamana ve geleceğe yansıması da o kadar güçlü olur. Aldığımız kararların uygun ve anlamlı duruma gelmesi, yine geçmişin bize öğrettikleri sayesindedir. Eğitim tarihinin bilinmesinin önemi ise eğitimsel anlamda düzenlenen etkinliklerin bilinmesi, günümüzün sağlıklı biçimde değerlendirilerek geleceğe dönük daha sağlam kararların alınmasının gerekliliğinden kaynaklanmaktadır (Alabaş, 2016; Ergün, 2008). Bu nedenle bu çalışmada dönemlere göre etki gösteren görüşlerin eğitim sistemini nasıl etkilediğinin çözümlenmesi gerekli duruma gelmiştir.

$\mathrm{Bu}$ çalışmada, Türk eğitim sistemine yön veren felsefi yapının tarihsel süreç içerisinde nasıl evrildiğini betimlemek amaçlanmıştır. $\mathrm{Bu}$ amaçla skolastik, modernizm ve postmodernizm dönemlerinde etkili olan düşünürler, fikirleri ve söz konusu dönem içinde geçerli olan felsefi yapıların eğitim sistemini nasıl şekillendirdiği kozmik yapı kavramı kullanılarak anlatılmıştır. Bunun için öncelikli olarak dönemler içinde yer alan düşünürlerin savunduğu felsefi görüşler, bu felsefi görüşlerin hangi akıma yön verdikleri ve nihayetinde ülkemizdeki eğitim sistemindeki gelişmelere yer verilmiştir. Çalışma, Ortaçağ'ın skolastik dönemi ile birlikte modernizm ve postmodernizme yön veren düşünürlerin görüşleri, eğitime etkileri ile 
sınırlı tutulmuştur. Bu kapsamda, alanyazın taranmış ve eğitim felsefesi üzerinde derin iz bırakan düşünürler, ayrıntılı bir şekilde incelenmiştir.

\section{Skolastik Dönem ve Eğitim Felsefesinin Yapısı}

Skolastik sözcüğü Latin kökenli bir sözcük olup scola kökünden türeyen ve medrese eğitimi verilen okul anlamına gelmektedir. Skolastik düşünce içinde değerlendirilen Hristiyanlık, felsefe ve akıl ile bağdaştırılmış aynı zamanda da Tanrı ve Kutsal kitabın sorgulanamaz olduğunu ilan etmiş, aksi durumlar için de kilisenin aforoz etme yetkisini gündemde tutmuştur (Güven, 2017). Sekizinci yüzyılla 15. yüzyıl arasındaki dönemi kapsayan skolastik dönem düşünürlerine göre en önemli şey doğaüstü varlık alanıyla ilişkidir. Ahlaklı olmak en büyük erdemdir. Vahiy, aklın yol göstericisidir. Var olan her şey, Tanrı merkezli araştırma kapsamındadır. Bu yönüyle statiktir (duruktur). Bu dönemin felsefecileri, realist (gerçekçi) görüş etrafında birleşmişler ve tümellerin insanın zihninden bağımsız olduğunu söylemişlerdir. Yine, uygulanan yöntem bakımından gelenek ve vahiy kapsamında üretilen otoriteye saygı ve uyum esastır. Eleştiri ve kuşkuculuğun yasak olduğu bir felsefe dönemidir. Kurumsal yapı içinde gelişen skolastik felsefe; manastır, katedral ve üniversiteler yoluyla teknik bir şekilde gelişmiştir. Bu dönemin eğitimi, okuma-yazma etkinlikleri ile sınırlıydı. Şövalye, lord olarak adlandırılan ve imparatorlukta söz sahibi olan kişiler okuma-yazma bilmiyordu. Bürokrasiye ait işler, kilisede görevli olan rahipler tarafından yapılmaktaydı. Eğitim dili Latinceydi ve dinsel bilgilere ilişkin erkek çocukların eğitilmesi ön plandaydı. Bu eğitim ise çocukların ailelerini taklit etmesi şeklindeydi. Katedral ve manastır eğitimleri, Ortaçă̆'ın ilk dönemlerinde trivium adı verilen hitabet sanatı (retorik), gramer ve diyalektik ile qudrivium adı verilen ileri düzey matematik, geometri, astronomi ve müzikten oluşan bir eğitim programı uygulanmaktaydı. Bu program üniversiteler için de geçerliydi (Sebetci, 2016).

On ikinci yüzyılla birlikte İtalya'da Bologna Üniversitesi, Paris ve Oxford Üniversitelerinin kurulmasıyla çok sayıda öğrenci yetişmiş ve Hristiyan felsefesi kendine özgü geleneksel özellikler oluşturmuştur (Cevizci, 2001). Üniversitelerin kuruluşundan sonra Fransisken ve Dominike tarikatları, üniversitelerde öğretilen bilimin yönü konusunda söz sahibi olmuşlardır. Fransisken tarikatı bilime yönelerek bilimsel düşüncenin gelişmesine, Dominiken tarikatı ise felsefeyi temel alan çalışmalar yaparak Hristiyan felsefesinin sistemleştirilmesine ve skolastik yöntemin yeniden düzenlenmesine katkı sağlamışlardır. Üniversite eğitimlerinde temel görev, eğitimdir. Antik Çağ'dan gelen Yunan ve İslami değerlere ilişkin bilgiler aktarılmış ve öğrenciler de kendilerine yöneltilen sorulara öğrendiklerini aynen tekrar ederek yanıt vermişlerdir (Antalyalı, 2007).

Dini eğitim temelli olan bu dönemin eğitim felsefesi, daimiciliktir (prennialism). Daimicilik eğitim felsefesi ise, idealizm ve realizm akımlarını temel alır. Gerçek, birdir ve bölünemez. Teolojide Tanrı'nın buyrukları her durumda geçerlidir ve soyuttur. Daimicilik eğitim felsefesinin temelinde felsefe, teoloji ve matematik vardır, tarih, edebiyat, estetiğe ilişkin eleştiriler ise hem kendi içinde birbirlerine hem de felsefe, teoloji ve matematiğe ters düşmemelidir. Bilgi, apriori (önsel) durumundadır, 
diğer bir deyişle doğru ve mutlak olan bilgi, insan aklında önceden vardır. Başat kültürel değerleri aktaran öğretmen, örnek olunup taklit edilen kişidir (Sönmez, 2015). Bu dönemde doğru ve değişmeyen bilginin öğrenciye sunulması eğitim anlayışına etki etmiş, insanın yapısının her yerde ve her zaman aynı olduğu kabul edilerek herkes için aynı eğitim içeriğinin sunulması gerektiği üzerine yoğunlaşılmıştır. Eğitimde öğrencilerin bilişsel ve duyuşsal yeteneklerini geliştirmek için tarih, mantık, dil, edebiyat ve matematik derslerine yer verilmeye çalışılmıştır. Bu dönemin eğitim uygulamaları bireysel farklılıkları dikkate almamış, eşitlik ve özgürlük kavramlarını göz ardı eden bir yaklaşım benimsenmiştir.

Skolastik felsefenin özünde Aristoteles vardır. Bilimle ilgili en önemli etkinlik, Aristoteles'in eserlerini, yöntemini çözümleme çalışmalarıdır. Akıl ve mantık, dini dogmaları açıklamak için araç olarak kullanılmıştır. Amaç ise insanoğlunun kurtuluşa ermesidir. Tarih içinde gösterdiği sürece bakıldığında skolastik felsefe; erken dönem skolastik felsefe, yükselme dönemi skolastik felsefe ve son dönem skolastik felsefe olmak üzere üç bölümde değerlendirildiği görülmektedir. Erken dönem skolastik felsefe 8. ve 9. yüzyıllara (800-1200 yılları arası) karşılık gelir ve bu dönemde Johannes Scottus Eriguena teoloji ve felsefeyi akılla bütünleştirmiş, dinin gerçeklerinin akıl temelinde kabul edilmesi gerektiğini savunmuştur. Aziz Anselmus ise anlamak için inanıyorum diyerek inancı akıl ile temellendirmiştir (Küçük, 2015). Skolastik felsefenin yükselme dönemi (1200-1300 yılları arası) Batı'nın İslam felsefesi ile tanışması ve İslam felsefecilerinden İbn-i Rüşd ve İbn-i Sina'nın Aristoteles'in eserlerini Arapçaya çevirerek ve Aristoteles'in aynı zamanda sadece mantığını değil, aynı zamanda ontoloji ve metafiziğini de öğrenmesi ile başlar. Bir başka deyişle İslam dünyası Batıdan çok daha önce Aristoteles ile tanışmış ve Aristotelizm akımını başlatmıştır (Gökberk, 2003). Yine dönemin düşünürlerinden Thomas Aquinas'a göre, deney bilginin kaynağıdır ve devleti yönetenlere itaat önemlidir. Devlet, Tanrı ile insan arasında bütünleşmeyi sağlar (Küçük, 2015). Skolastik felsefenin son döneminde (1300-1500 y1lları aras1) ise bu felsefe eleştirilmeye başlar ve 9-12. yüzyıl aynı zamanda felsefi anlamda durağanlığın yaşandığı dönemdir. Bu dönemde Ockhamlı William, Tanrı'nın varlığının kanıtlanamayacağını ve Tanrı ile dünyayı aşan bilgilerin ancak önerme olarak kabul edilebileceğini söylemiştir. Felsefe aklın, Tanrıbilim kanıtların ürünüdür. Bu düşünceleri ile William, bilgiyi ve inancı birbirinden ayırmıştır (Bayar, 2001).

Skolastik döneme İslam felsefesi açısından bakıldığında İbni-Sina, İbn-i Rüşd, Farabi ve Gazali'nin felsefi çalışmalarına değinmek gerekir. El-Kindi, İslam felsefesinin oluşum döneminin felsefecisidir. İlk Arap felsefecisi olan İslam felsefesinin ünlü simalarından El-Kindi çalışmalarını Yunan filozoflarından Aristo ve Eflatun'a (Platon) dayandırmış, Aristo'nun “De Anima (Ruh Üzerine)” adlı eseri üzerine açıklamalı kitap yazarak felsefe ile uğraşmanın erdemli bir hareket olduğunu dile getirmiş, felsefi yöntemini kanıtlama ve sonul (nihai) amacını da Allah'a yaklaşmak olarak açıklamıştır. O’na göre bilginin ilk basamağı akıldır. Doğu'da Muallim-i Evvel (birinci öğretmen) olarak adlandırılan Aristo'dan sonra Muallim-i Sani (ikinci öğretmen) olarak anılan ve İbni-i Sina ile İslam felsefesinin yaratıcı 
dönemini oluşturan Farabi (Küçük, 2015) ise, felsefeyi esas alır ve çalışmalarında İslam nasslığı (kesinlik, netlik), Aristo, Eflatun'un etkisi altındadır. Farabi'nin önemi felsefe ve İslam'ı bütünleştirmede gösterdiği başarıdır ve çalıșmaları Ortaçağ Skolastik felsefe dünyasını derinden etkilemiş ve yönlendirmiştir (Çüçen, 2000). Gazali ise, Aristotelesyenlerin felsefesi üzerine eleştirilerde bulunmuş ve her şeye gücü yeten bir irade özünden söz etmiştir (Rescher, 2005). Bu dönemde Batı'da ve Arap dünyasında eğitim alanında bu gelişmeler karşılı̆̆ında Türklerde eğitim anlayışını sözlü kültür ürünleri oluşturmuştur. Eğitimin yaygın eğitim şeklinde olduğu bu toplumlarda eğitimi, göçebe yaşam tarzı şekillendirmiştir. Göçebe ve savaş̧̧ı bir toplum olan Hunlar'da savaş ve yöneticilik eğitimi; Göktürkler'in kendilerine özgü geliştirdikleri alfabe ile yazılı eserler bırakmaları bu dönemin belirgin özellikleri arasında yerini almıştır. Yerleşik yaşama geçerek eğitimi kurumsal duruma getiren Uygurlar'da din adamları eğitim işini üstlenmiş, ibadet yapılan yerler kütüphane ve eğitim alanı olarak kullanılmış, matbaa ile birlikte kitapların basılarak çoğaltılmasına olanak tanımıştır (Hali ve Rencüzoğulları, 2017).

Nizamü’l-Mülk tarafından yaptırılan Nizamiye Medresesi ve sonraki dönemde açılan medreseler, Büyük Selçuklu Devleti ve Osmanlı Devleti'nde ortak bir amaç etrafında birleşen, ortak bir düzene sahip ve kendini yönetebilen bir eğitim kurumu olarak işlev görmüştür. Osmanlı eğitim sistemi, Türk örflerine ve İslami ilkelere göre şekillendirilmiştir. Öğretmen merkezli bir eğitim sistemi benimsendiği için öğretmenin anlattığı, kitaplarda yazılanlar ve İslam bilginlerinin verdiği bilgiler doğru olarak kabul edilmiştir. Öğrencilerin verilen bilgileri tartışmalarına ve sorgulamalarına izin verilmez, ezberleyip aynen tekrar etmeleri istenirdi. 16. yüzyılın ikinci yarısına kadar medreselerde bilim, araştırma, inceleme, gözlem, kuram ve uygulamayı birlikte götürme ön planda iken özellikle 17. ve 18. yüzyıllarda, Osmanlı medreselerindeki eğitim sistemine Skolastik Düşünce egemen olmuş ve İslam bilginlerinin söylediği her söz koşulsuz doğru kabul edilmiştir (Sönmez, 2015). Merkezden yönetim anlayışının temeli ise Osmanlı Devleti'nde 1857 yılında ilk eğitim bakanlığı olan Maarif-i Umumiye Nezareti'nin kurulması ile atılmıştır (Özdemir, 2008). Bu Nezaretin kurulmasının ardından 1869 yılında Sultan Abdulaziz döneminde Fransız eğitim sistemi temeline oturtulan ve 1913 yılına kadar yürürlükte kalacak olan Maarif-i Umumiye Nizamnamesi hazırlanmış, 1870 yılında bu Nizamname uygulamaya konulmuştur. Bu Nizamname ile ilköğretim zorunlu duruma getirilmiş, öğretmenlik okulları açılmış, kız çocuklarının eğitimine önem verilmiş, karma eğitim anlayışı benimsenmiştir. Yine bu dönemde geleneksel eğitim yerine laik modern eğitim sistemi benimsenmiş (Çağır ve Türk, 2017) ve okullarda Gaspıralı İsmail Bey’in Usûl-u Cedîd adını verdiği günümüzdeki ses temelli cümle yöntemine benzeyen kırk günde okuma-yazmanın öğretildiği eğitim sistemi benimsenmiştir (Arslan, 2016).

\section{Modernizm ve Eğitim Felsefesinin Yapısı}

On dokuzuncu yüzyıla gelindiğinde modernizm kavramı, 1910-1945 yılları arasındaki sanat ve bilime ilişkin siyasi, tarihi, kültürel ve estetikle ilgili gelişmeleri 
belirtmek için kullanılmıştır (Goldman, 2004). Modern felsefe ile evren ile Tanrı arasındaki bağ ayrıştırılmış, evrenin doğa yasaları tarafından yönetildiği ve maddi kavramlarla açıklandığı çalışma alanı durumuna gelmiştir. Bilim, bu dönemde pozitivizm kavramı üzerinde yoğunlaşmış ve insanın/insanların gereksinimlerinden üretilmiştir. Davranışlar, inanç ve duygu temelinden uzaklaşmış, olaylar arasındaki mantıksal ilişki esas olmuştur (Keha, 2016). Ortaçağ boyunca eğitim dili Latince olmuş, Rönesans sonrası dönemde yenidünya uluslarının ortaya çıkması ve toplumlardaki modernleşme sürecine bağlı olarak anadilde eğitim süreci başlamıştır (Gümüş, 2010). Bireyselleşme, seküler olma, bürokratikleşme, endüstrileşme, şehirleşme, evrensel olma modern toplumlardaki eğitime bakış açılarını da belirtir. Bu döneme hakim olan pozitivizm ile okullar, önceden belirlenen kurallara göre insan yetiştiren bir kurum olarak değerlendirilmiştir. Klasik yönetim kuramlarının eğitim örgütlerine uygulanmasıyla birlikte sahip olunan inanç ve değerler sisteminin, örgüt amaçlarının gerçekleştirilmesi için ihmal edilebileceği inancını yaygınlaştırmıştır (Aslanargun, 2007).

Skolastik dönemde geçerli olan baskıcı, şekilci ve tutucu eğitim anlayışının yerine modernizmle birlikte eğitim, öğrencilerin çıkarları ve ilgi alanlarının önemli olduğu anlayışına dayandırılmış, öğrenciler gerektiğinde eleştiren ve sorun çözmeye odaklanan bir yapı içinde yetiştirilmeye çalışılmıştır. Cumhuriyet döneminin eğitim sistemi ise, pragmatik felsefe ve ilerlemecilik (progressivizm) akımına dayanır. Uygulamada ise esasicilik ve daimicilik esas alınmıştır. Öğrenci merkezli öğrenmenin yerine, kültürel mirasın temsilcisi olarak görülen öğretmen ve konuların merkeze alındığı, otoritenin ve cezanın elden bırakılmamasının gerektiği ve bildiklerinin her koşulda doğru olduğuna inandırılan kişilerin yetiştirildiği bir eğitim sistemi benimsenmiştir. Modernizm, Latince modernus sözcüğüne karşıllk gelir ve ilk kez 5. yüzyılda dinsizliği reddetmek ve Hristiyan olan toplulukları belirtmek amacıyla kullanılmıştır. Rönesans döneminin düşünürleri ise modern sözcüğünü Batılı olanı belirtmek için kullanmıştır. Aslında 15. ve 20. yüzyılı kapsayan modernizm, Aydınlanma Çağı'na girilmesiyle birlikte söz konusu kavram, daha önce kullanıldığı anlam doğrultusunda fakat daha da geniş bir anlamı belirtir olmuştur (Keha, 2016).

$\mathrm{Bu}$ dönemin en önemli felsefecilerinden Francis Bacon'a göre bilgi güçtür ve insanoğlu bilgi ile doğaya egemen olmalıdır (Keha, 2016). Modern felsefenin babası olarak kabul edilen René Descartes ise kuşkuculuk kavramını, matematik ile ilişkilendirerek matematiksel önermelerle akıl yürütmenin sağlamlığı ve kanıtlama işleminin kesinliği üzerinde durmuştur (Secada, 2004). Bu dönemin güçlü isimlerinden ve aydınlanma felsefesinin kurucusu olarak kabul edilen John Locke, eğitimde yararlı ve doğal olanın esas alınması gerektiğini söylemiştir. Eğitimde ampirist (deneysel) akımı savunan Locke, insan zihnini doğuştan boş bir levhaya benzetmiş ve insana öğretilenlerin sonradan kazanılan yararlı bilgilerden ibaret olduğunu savunmuştur. Eğitimde etkin öğrenmeler üzerinde duran Locke, sağlıklı bir zihinsel işleyişin sağlıklı bir bedenle olanaklı olacağını dile getirmiştir. Çocukların öğrenmeleri üzerinde dayağın bir eğitim aracı olamayacağını ve ödüllendirmenin önemi ile erdemli öğrenciler yetiştirmenin üzerinde durmuştur (Cihan, 2010). Yine 
dönemin Cenevreli filozoflarından Jean-Jacques Rousseau, Emile adlı kitabında geleneksel eğitime karşı çıkarak kitabını herkesin bildiği şeylerle doldurmak istemediğini belirtmiştir. Eğitimde en iyi bilimsel araştırma yönteminin doğa olduğunu, insan aklı ile doğanın uyum içinde çalışarak insanın eğitimine etki edeceğini belirterek naturalizme dayalı bakış açısı sergilemiştir (Rousseau, çev. 2009). Çă̆daş felsefenin bir diğer temsilcisi Immanuel Kant, insanın özü itibariyle iyi bir varlık olduğunu dile getirmiş ve eğitimde deneysel yönteme ağırlık vermiş, çağdaş ve evrensel kavramlarını eğitim sistemine kazandırmıştır. "Din eğitimi, ahlak üzerine inşa edilmelidir” (Çilingir ve Küçükali, 2004, s. 88) diyerek etiğe ilişkin görüşlerini alana kazandırmıştır. Kant'a göre ödül alma isteğine yönelik sergilenen ya da ceza almaktan korkularak yapılmayan bir davranışın ahlaki değeri yoktur (Yayla, 2005). Hegel ise, insanı yüceltmede ve geleceğe yön vermede eğitimin önemi üzerinde durmuştur (Hausmann, çev. 1957). Auguste Comte tarafından 19. yüzyılda felsefi anlamda kullanılan pozitivizm kavramı bilim içinde değerlere yer verilemeyeceğini belirtmiş, gözlem ve deneyin kesin bilgiye ulaşmada tek kaynak olduğu iddiasında bulunarak ampirik olay ve olguları incelemiş, dünyada klasik kuramcıları dolayısıyla ülkemizi de etkilemiştir. Bu anlayış sonucunda gelişen bakış açısına göre eğitim örgütleri; sağduyu ile barışık, bürokratik uygulamaların esas olduğu, hedefi olan ve hedefin gerçekleşmesine yönelik eylemlerde bulunan kurumlardır (Fırat, 2006). Yine düşüncelerini ampirizm üzerine temellendiren David Hume da zihindeki algıları izlenimler ve ideler olmak üzere ikiye ayırmıştır. İdeler; hayal gücüne ilişkindir, izlenimler ise açıkça vardırlar ve var olduklarının ispatı herhangi bir şeye bağlı değildir (Pereira, 2006). Eğitimi pragmatizm felsefesi ile ilişkilendiren ve bilgiyi araç olarak gören Davranışçı yaklaşımın temsilcilerinden John Dewey, doğru olarak kabul edilen bilginin, yenisi ortaya çıkıncaya kadar kabul edildiğini ve değişime açık olduğunu belirtmiştir. Doğru, iyi ve güzel olanın bir yararı olmalı, okul ise kültürel, toplumsal, pedagoji ve ekonomik yönlerden gelişmenin merkezidir (Güçlüol, 1985). Dewey'in eğitim anlayışında pragmatist felsefe, yeniden kurmacılık akımının temelini oluşturmaktadır. Bu akımın savunucuları ise John Dewey’in yanısıra Isaac Bergson, Theodere Brameld olup eğitimin yeni bir toplum düzeni oluşturması, toplumsal değişimin kaynağının okullar olduğunu ve davranış bilimlerinin bulgularından yararlanılması gerektiğini belirtmişlerdir (Kocabaş, 2008).

Türk eğitim sisteminin felsefesine yön veren kişiler, II. Meşrutiyet dönemine denk gelir. Bu dönemde Emrullah Efendi’nin Tuba Ağacı Nazariyesi’ne karşılık Satı Bey'in fikirleri günümüz eğitim sisteminde de karşılık bulmaya devam etmektedir. Emrullah Efendi, Tuba Ağacı Nazariyesi'nde dünyanın her yerinde yükseköğretime verilen önemden dolayı eğitim reformlarının önce yükseköğretimden başlanılması gerektiğini ve yükseköğretim görmüş aydın kişilere gereksinimimiz olduğunu söylemiştir. $\mathrm{Bu}$ fikre karşı çıkan Satı Bey ise eğitim alanındaki reformlara ilkokullardan başlanılması gerektiğini iddia etmiştir. Temeli sağlam olmayan bir ilköğretim sistemi, yükseköğretimin gelişimine katkıda bulunamaz. Tanzimat Dönemi'nde kurulan Darulfünun'un başarısızlığını da eğitimle ilgili reformlara yukarıdan başlamakta bulur. $\mathrm{Bu}$ dönemdeki eğitim alanına hakim olan anlayış 
Cumhuriyet döneminde de etkilerini göstermeye devam etmiştir (Aksoy, 2008). Eğitim kurumları olan medreseler yenilenerek sosyal, siyasal içerikli ve yaşam becerisi kazanmaya yönelik dersler medreselerin eğitim programlarına konulmuştur (Kocabaş, 2008). İkinci Meşrutiyet döneminin önde gelen fikir adamlarından biri ve aslen sosyolog olan Ziya Gökalp, eğitim ile ilgili düzenlemelere öncelikle üniversitelerden başlayarak daha aşağıdaki kademelere doğru inmesi gerektiğini savunan Emrullah Efendi'nin Tuba Ağacı Nazariyesi'ni desteklemiş ve eğitimde ezberci eğitimden uzak durulması, öğrencilerin sosyal yaşama uyum becerileri sergilemeleri gereken bilgilerin sunulması ve ulusal bir eğitim anlayışının geliştirilmesinden yana tavır sergilemiştir. Öğretmenlerin kendilerini sağlıklı bir şekilde ifade edebilmesinin yolunu açan felsefe ve sosyoloji dersi eğitimi almalarının önemine değinen Gökalp, öğretmene değer verilen yaklaşımın benimsenmesiyle eğitim sisteminde var olan pek çok sorunun aşllabileceği düşüncesini savunmuştur (Altın, 2010). Özellikle John Dewey'in eğitim ile ilgili görüşleri, ülkemizde de dikkat çekmiş ve yeni kurulan Türk Devleti'nin eğitim sistemine ilişkin görüşlerini almak üzere 1924 yılında Türkiye'ye davet edilen Dewey, iki ay boyunca ülkemizdeki Türk Milli Eğitim Sistemi’ne ilişkin iki ayrı rapor hazırlamıştır. Bu raporlardan biri bütçelemeye ilişkin, diğeri ise eğitim sistemimize ilişkin gözlem ve önerilerine yöneliktir. Bu raporda ise, okulda öğrencilere işe yarar ve sosyal yaşamda kullanabilecekleri bilgiler sunulması, eğitimde öncelikle hedef saptamasının yapılması, Eğitim Bakanlığının ve gezici kütüphanelerin kurulması, okul yapım işlerinin ve öğretmen niteliğinin yükseltilmesi için çalışmaların bu bakanlık tarafından örgütlenmesi ile ilgili gözlem ve öneriler yer almıştır. John Dewey'in bu gözlem ve önerileri eğitim sistemimizde karşılık bulmuş; ülkemizdeki davranışçı eğitim uygulamaları, 3 Nisan 1926 gün ve 789 sayılı Maarif Teşkilâtı Kanunu'nda, eğitim sistemimizin planlı hale getirilmesinde, öğretmen okullarının çeşitlendirilmesi ve mesleki-teknik eğitim uygulamalarının geliştirilmesinde etkisini göstermiştir (Güçlüol, 1985). Bu dönemde aydınlanma felsefesinin ve idealist felsefenin yansıması olarak 17 Nisan 1940 tarihinde çıkarılan yasayla farklı alanlarda görev yapacak meslek elemanları yetiştirilmesi amacıyla Köy Enstitüleri açılmıştır (Eyyupoğlu, 2017).

\section{Postmodernizm ve Eğitim Felsefesinin Yapısı}

Postmodernizm sözcügü 1930'lu yıllardan bu yana Latin Amerika'da edebiyat ile eleştirileri dile getirmede, 1940'll yıllardan itibaren de modernizmin estetik kavramı ile ilişkisini yeni bir biçim tasarlamak üzere Anglo-Amerikan tartışmalarında kullanılmaya başlanmıştır. Sosyolojide ise Amitai Etzioni'nin "Aktif Toplum" adlı eserinde tanıtılmıştır (Smelter ve Baltes, 2001). Ülkemizde ise postmodernizm kavramı, modernizm ötesi olarak değerlendirilmiştir. Postmodernizm, modernizme ait olan özellikle Aydınlanma Çağı'na ait bütün özelliklerin sorgulanması, bu özelliklere eleştirel gözle bakıp değerlendirme yapılmasına dayanır (Bayram, 2007). Postmodernizm; modern olanın sorgulanması, öğrencinin ön bilgilerden hareketle bilgiyi yapılandırması, bilginin öznel oluşu, eleştirel bakış açısı, öğrencinin öğrenme sürecinde etkin olması, eğitim ortamında öğretmenin otoriteden uzak rehber olarak 
yer alması, çoğulculuk anlayışının egemen oluşu ile eğitim sistemine etki etmiş ve tüm dünyadaki eğitim uygulamalarını içerik ve biçim yönüyle şekillendirmiştir (Kılıç ve Bayram, 2014). Postmodern eğitim anlayışı, ötekileştirilmiş olan kişilere söz hakkı verilmesini ve düşüncelerini açıklanmasına firsat verilmesini ister. Bu dönemin eğitim kavramı, öğrencilerin sadece neyi öğrendikleri ile ilgili değil aynı zamanda nasıl öğrendikleri ile de ilgilidir. Eğitim; diyalog, kültürel çeşitlilik ve popüler kültür kavramlarının sosyal yapı içinde anlamlı duruma getirilmesini, öğrencilerin yönetmek için eğitilmelerini ve halk liderliği yoluyla rollerini ahlaki sorumluluk içinde yerine getirmelerine katkıda bulunmalarını sağlayacak bilgi ve becerilerin kazanılması ve sergilenmesini de sağlamalıdır (Kurt, 2006). Postmodernizm döneminin düşünürleri ise insan ve toplumu ya da insanın dışında yer alan dünyaya ilişkin gerçekliği temsil edecek ya da açıklayacak kuramsal bilginin yapılamayacağı görüşünü dile getirmişlerdir. Çünkü toplumda parçalanmışlık, karmaşa ve süreksiz olan durum vardır. Bu nedenle de insan ve toplum belirlenemez olgulardır. Savunulan diğer bir iddia ise, nesnel bir gerçekliğin olamayacağı görüşüdür (Şaylan, 2016; Uslu-Çetin ve Özdemir, 2019). Friedrich Nietzsche, Edmund Husserl, Michel Foucault gibi isimler postmodern felsefenin düşünürleridir (Bayram, 2007). Postmodern söylemin devamında da Alman filozoflar olarak bilinen Frankfurt Okulu da postmodernizmin ilkelerinin belirlenmesinde önemli akımlardan biri olarak kabul edilmiștir (Gül, 2016). Frankfurt Okulu kavramı yalnız Horkheimer için değil aynı zamanda Adorno, Marcuse, Habermas ve Wellmer'i de kapsayacak şekilde kullanılmıştır. Eleştirel Kuram Hareketi'nin temsilcisi olan bu kişiler, insanın hak ettiği değere kavuşması ve temelde pozitivizmin olgu ve değeri birbirinden ayıran anlayışına karşı duran görüşlerini biçimlendirmişlerdir (Guess, 1981).

Postmodernist dönemin yapılandırmacı anlayışı, ülkemizde İngilizce'deki constructivism sözcüğ̈̈ ile karşılık bulmuş ve bilginin temelden kurulması anlayışına dayandırılmıştır. Bilginin yeniden yapılandırılmasında, öğrencilerin bireysel özelliklerine, ilgi ve deneyimlerine yer verilir. Öğrenme, bilinen durumda olan bilginin öğrencinin zihninde yapılandırılmasıyla oluşur. Öğretmen, rehber rolündedir (Karadağ, Deniz, Korkmaz ve Deniz, 2008). Davranış̧̧ılık üzerine geliştirilen yaklaşımların istenilen becerilere sahip insan gücünü yetiştirememesi nedeniyle yapılandırmacılık felsefesi üzerine geliştirilen yaklaşımlar, ülkemizde de 2005-2006 öğretim yılından itibaren öğretim programlarında uygulanmaya başlamıştır (Çakır ve Doğan, 2017). Ülkemizde eğitim programlarındaki değişim öncelikli olarak ilkokullarda başlamış daha sonra ortaöğretimde devam etmiştir. Eğitim programlarımızdaki değişime Howard Gardner'ın zekanın birbirinden farklı ve birbirinden bağımsız çalışan sekiz bileşeni olduğunu, bir etkinlik için birkaç zeka bileşeninin birlikte çalıştıılması gerektiğini savunduğu Çoklu Zeka Kuramı (Başaran, 2004), Lev Seminoviç Vygostky'nin öğrenme süreçlerinde kültür ve toplumun önemini vurguladığı Sosyal Yapılandırmacılık Kuramı (Baş ve Beyhan, 2017), Caine'nin beyin içindeki nöronlar, etkinlikler yoluyla ne kadar çok etkin duruma getirilirse o zaman anlamlı ögrenmenin olacağı ve bilgilerin öğrenciler tarafindan yeniden yapılandırıldığı için beyin temelli olacağını belirttiği Beyin Temelli Öğrenme 
Kuramı (Demirel, 2011), Richard W. Paul'un öğrencilerin ya da kişilerin kendi öğrendikleri temelinde düşüncelerini şekillendirdiği ve değerlendirdiği süreç olarak tanımladığı Eleştirel Düşünme Kuramı (Seferoğlu ve Akbıyık, 2006) bağlamında esnek öğrenme, yaratıcı düşünme, proje tabanlı öğrenme, işbirliğine dayalı öğrenme, hayat boyu öğrenme modelleri damgasını vurmuştur. Programın temelinden eklektik anlayış benimsenmiştir, diğer bir deyişle farklı kuramsal temeller üzerine oturtulan bir program anlayışı söz konusudur (Akınoğlu, 2005).

Nietzsche, bireyler için özgürce gelişmelerine olanak sağlayan bir eğitim modeli tasarlamış ve bu eğitim sonucunda bireylerin hedefler koyarak diğer insanlara yol göstereceğini belirtmiştir (Kabadayı, 2001). Fenomenoloji (olgubilim) felsefi akımının kurucularından Husserl, fenomenolojinin parolasını yeniden şeylere (fenomenlere) dönülmeli olarak belirlemiş (Mengüşoğlu, 2012), özü sezgisel olarak anlayıp kavramanın önemine değinmiştir. Özü algılamak ise, uzun ve karmaşık bir süreci gerektirir. Husserl'ın bu görüşleri, Varoluşçu Felsefe ile Yeni Ontolojinin ortaya çıkmasına katkı sağlamıştır (Öktem, 2005). Foucault'ın öne sürdüğü yönetimsellik kavramı ile yönetim ve bilgi arasındaki bağa işaret etmekle birlikte, eğitim politikalarını anlamada en önemli öğedir. Yönetimsellik, aynı zamanda davranışları yönetmektir. Öğrenme ise, eğitim ve öğretime ilişkin örgütlenmede bir araçtır. Eğitim yönetiminin tedavi edici bir işlevi vardır ve bireylerin normalleşme sürecine uyum sağlamalarına yardımcı olur. Yönetici ve öğretmenler ise bu sürece yardımcı olan kişiler olarak görev yaparlar (Şentürk ve Turan, 2012). Frankfurt Okulu, bu dönemde Eleştirel Kuram'ın temsilcisi olmuştur. Bu okulun temsilcilerinden Horkheimer'a göre bilgi ve eylem bir bütündür. Araştırmacı incelediği nesnenin parçasıdır. Sosyal bilim kavramının kuramsal açıklamalardan ve felsefi arka plandan uzak tutulamayacağını savunmuştur. Habermas ise, pozitivizmi eleştirmiş ve sosyal bilimler ile doğa bilimlerini birbirinden ayırmıştır. Doğal bilimlerdeki nesnellik, sosyal bilimlerdeki yorumlama-anlamaya yönelik usul özelliklerinden dolayı doğrudan sosyal bilimlere aktarılamaz (Durdu, 2006).

Pek çok sosyal yapıda olduğu gibi, eğitim örgütleri de içinde yaşadıkları toplumda meydana gelen olaylardan üretilen fikirsel akım ve ideolojilerin etkisi altında kalır. Doğal olarak da toplumda görülmek istenen birey modeli içinde bulunulan özelliklere göre değişmekte ve eğitim-öğretimde uygulanan politika ve programlara da yön vermektedir (Çakır ve Doğan, 2017). İlerlemeci eğitim yaklaşımının öğrenciye ve onun eğitimine verdiği önemin eleştirilmesi üzerine, çocukların öncelikle yaşadıkları toplumun bir üyesi olduklarına inanmaları ve toplumun sürekli değişim içinde bulunmasından dolayı bilginin de her an değişebileceği, öğrencinin gelişiminde eleştirel düşünme, bilimsel yöntemi kullanma becerisi kazanma, eğitim aracılığıla toplumun yeniden kurulmasında ve dolayısıyla da öğrencinin yetiştirilmesinde kültürel ve sosyal yönden yeniden yapılandırma eyleminde bulunulması eğitim felsefesinin oluşumuna etki etmiștir. Cumhuriyet dönemi ile başlayan ve ilerlemecilik üzerine şekillenen eğitim sistemimiz, yapılandırmacılık temelli kuramların da etkisiyle Yeniden Kurmacılık eğitim akımının etkisi altında şekillenmiştir. Bu akım, pragmatizme dayanmakla birlikte 
yaşam sürekli değiştiği için eğitim bu değişikliklere uyum sağlamada denge aracı olarak kabul edilmiştir. Sınıf ortamının demokratik olması, uygulamaya ağırlık verilmesi, yeni öğrenme ve öğretme teknikleri geliștirilerek dönüt, düzeltme, pekiştirece yer verilerek cezanın kesinlikle kullanılmaması gerektiği savunulmuştur.

Postmodernizmle birlikte eğitimde nitelik sorunu üzerinde çalışmalar hız kazanmış ve yapılandırmacılık (constructivism), eğitim uygulamalarına yön veren en önemli felsefi akımlardan biri olmuştur. Nitelik sorunu ile ilgili çıkmazın yaşanmasında uluslararası düzeyde yapılan Uluslararası Öğrenci Değerlendirme Programı (PISA), Uluslararası Matematik ve Fen Eğilimleri Araştırması (TIMMS) gibi sınavlarda başarı düzeyinin düşük olması, eğitim örgütlerinde öğrenilen bilgilerin günlük yaşama aktarılması becerisi gösterilememesi gibi nedenler, yapılandırmacı yaklaşımın ana felsefesi olan önceki öğrenmelerin yeni karşılaşılan durumlardaki bilgilerle ilişkilendirilerek öğrenmenin gerçekleştirilmesi ve öğrenci öğrenmesine dayanması, eğitimin niteliğini yükseltmek isteyen eğitim politikacıları tarafından ilgiyle karşılanmıştır (Arslan, 2007). Bu dönemde eleştirel eğitim felsefesinin öncülerinden Paulo Freire, "Ezilenlerin Pedagojisi" adlı kitabında eğitimde var olan geleneksel eğitime yönelik eleştirilerde bulunmuş, eğitimde var olan otoriter tavrı ortadan kaldırarak özgür bireyin gelişimine katkı sağlayacak sorun tanımlayıcı eğitim modelini önermiştir. Bu modelde öğretmen hep algılayan konumundadır, kendi düşüncelerini öğrencilerin düşünceleri içinde sürekli olarak yeniden şekillendirir. Öğrenciler ise, öğretmenleriyle iletişim halinde ve eleştirel araştırma ortaklarıdır. Okur-yazar olma; kişinin niyetini, yaratıcıllğını ve eleştirilerinin ifade etmesi için araçtır (Freire, çev. 2017). 21. yy becerileri olarak adlandırılan (i) eleştirel düşünme ve sorun çözme becerisi, (ii) yaşamın farklı katmanları arasında işbirliği kurma becerisi, (iii) inisiyatif alma ve girişimcilik, (iv) sözlü ve yazılı iletişim, (v) bilgiye ulaşma ve bilgiyi işleme becerisi, (vi) meraklanma ve hayal kurma becerileri (Cemaloğlu, 2019) ülkemiz eğitim sisteminde yeni politikaların oluşumuna zemin hazırlamıştır. 2023 Eğitim Vizyonu Belgesi eğitimin merkezine insan öğesini almış, ontoloji ve epistemoloji birlikteliğini beceriyi ve milli- manevi değerleri kazandırmayı içeren ahlak görüşüyle harmanlamıştır (Milli Eğitim Bakanlığı, 2020).

\section{Tartışma, Sonuç ve Öneriler}

Eğitim, belirlenen amaçlar doğrultusunda kişilerin davranışlarına yön verecek eylemde bulunulmasını sağlama sanatı olduğu düşünüldüğünde, felsefi görüşler açısından da eğitime yüklenen anlamlar da değişmektedir. Tarihsel süreç içerisinde düşünme eylemi sonucunda oluşan felsefi yapı, dönemlere göre farklı temele oturtulan akımlar özelinde eğitim sistemine yön vermiştir. Özellikle idealizm, realizm, pragmatizm, pozitivizme dayalı felsefeler eğitim süreçlerinde etkisini göstermiştir. Felsefe, bir düşünme eylemidir. Felsefe, düşünme eylemi olması yönüyle eğitim sisteminde de kuram ve uygulama temelinde etkinliklerin üretilmesine katkı sağlar. Felsefi düşünme biçimleri, bir yandan kurumsal yönetim alanına farklı bir bakış açısı sağlarken diğer yandan da eğitim sistemine kılavuzluk eder. Bu çalışmada Türk eğitim sistemine yön veren bütüncül bir yaklaşım, düşünürler ve felsefi akımlar temelinde 
incelenmiştir. Bu amaçla, Türk eğitim sistemine yön veren felsefi yapı, skolastik dönem, modernizm ve postmodernizm olmak üzere üç dönem olarak incelenmiş ve bu amaç doğrultusunda her döneme yön veren düşünürler, felsefeleri ve her dönem içinde gelişen felsefi akımların eğitim sistemine ilişkin etkileri betimlenmiştir.

Çalışmanın ilk bölümünü oluşturan skolastik dönemde etkisini gösteren idealizm akımına göre eğitim, insanoğlunun Tanrı'ya ulaşma çabası olarak değerlendirilirken realizm (gerçekçilik) eğitimi geçmişten gelen kültürel birikimin bireylere aktarılarak topluma uyum sağlamalarının bir aracı olarak görülmüştür. Bu yönüyle idealizm, Ortaçağ eğitim felsefesine yön veren skolastik düşünce tarzına aktarmacı, muhafazakâr, kural koyucu eğitim anlayışına kaynaklık etmiştir. Bu dönemin ünlü düşünürleri ise bu dönemin felsefi anlayışına dayalı düşünce yapıları üretmişler ve bu doğrultuda gelişen düşünceler de eğitim anlayışına yön vermiştir. Bilginin ve var olan kültürün aktarılması yönüyle muhafazakar bir kimlik taşıyan bu dönemin eğitim sistemi, eğitimin en eski görevini yerine getirmiştir. Temelini idealizm ve realizm felsefe akımlarından alan daimicilik ve esasicilik, insan aklının boş olduğu ve insan aklının geliştirilmesi gerektiği, disiplinin esas alındığı geleneksel bir anlayış içinde kendine yer bulmuştur. Türk eğitim sistemi açısından ele alındığında, ilk Türk devletlerinde göçebe bir yaşamın olması, eğitimi yaşamda kalma çabaları yönünde şekillendirmiştir. İlerleyen zamanlarda ise din adamları eğitimle ilgili etkinliklerin sorumluluğunu üstlenmiş ve ibadet yapılan yerler eğitim yapılan yerler olmuştur. Özellikle Büyük Selçuklu Devleti ve Osmanlı Devleti dönemlerinde açılan medreseler, eğitimin planlı bir eylem olarak yürütüldüğg̈ mekanlar olmuştur. $\mathrm{Bu}$ kurumlarda da skolastik dönemin eğitim felsefesi etkili olmuş, iyi olana uygun davranış sergilemek ön planda tutulmuştur.

Çalışmanın ikinci bölümünde modernizm dönemi ile özdeşleşen akım pragmatizm (yararcılık) ise eğitimi, yaşantılar yoluyla kişi davranışlarının yeniden şekillendirmesi olarak yorumlarken naturalizm (doğacılık) eğitime bireylerin olgunlaşma düzeylerinin doğal yoldan artırılması ve olgunlaşan bu davranışı sergilemesi yönüyle bir bakış açısı geliştirmişlerdir. Realizm (gerçekçilik) ise dünyaya fiziki gerçeklik yönünde bir bakış açısı sergilemiştir. Özellikle modernizm dönemini etkileyen ilerlemeci eğitim felsefesi kaynağını pragmatizmden almıştır. Öğretmen, öğrencinin kılavuzu (rehberi) olmalı ve sorun çözmeye odaklanılmalıdır. Okul yaşamın kendisi olmalıdır anlayışından hareketle davranışsal yaklaşım modelleri eğitime yön vermiştir. İlerlemecilik (progressivism) eğitim felsefesi, pragmatizmin eğitime uygulanan şeklidir ve yeniden kurmacılık (reconstructionism) eğitim felsefesine dayanır. Toplumun yeniden inşa edilmesi gerektiğine ve bunun da eğitim yoluyla gerçekleşeceğine vurgu yapar. İlerlemecilik eğitim felsefesi, modernizm dönemi ile eğitim sisteminde varlı̆̆ını göstermeye başlamış, değişimi gerektiren yönüyle de yeniden kurmacılık eğitim felsefesinden ayrılmıştır. $\mathrm{Bu}$ yönüyle yeniden kurmacıllk eğitim felsefesi, dünyada ve özellikle ülkemizde eğitim sisteminin yeniden düzenlenmesi ve yapılandırılmasında işlerlik kazanmıştır. Modernizm döneminin etkilerini Türk eğitim sisteminde cumhuriyetin ilanı ile birlikte yeni Türk devletinin yeniden inşa edilmesi sürecinde görmek olanaklıdır. 
Kozmik yapıda bu dönemi etkisi altına alan pozitivist uygulamalar, medreselerdeki eğitim sisteminin yeniden yapılandırılması, eğitim veren kurumların tek çatı altında birleştirilmesi ve eğitim işlerinden sorumlu bir bakanlık kurulması, üniversite kurulması, köy enstitülerinin açılması uygulamalarında kendini göstermiştir.

Çalı̧̧manın üçüncü bölümünde postmodernizm döneminde etkisini gösteren ilerlemecilik akımının devamı sayılan yeniden kurmacılık akımı, modernizm döneminde etkisini göstermeye başlayan pragmatizm felsefesine dayanır. Postmodernizm döneminde bilginin yeniden inşa edilmesi ve değer kavramları üzerinde odaklanılmıştır. Bu kapsamda üretilen eğitim politikaları, öğrencinin merkeze konulduğu ve öğretmenin rehber konumunda tutulduğu bir yapı izlemiştir. Postmodernizm dönemiyle ülkemizde yeniden kurmacılık akımıyla birlikte gelişen yaklaşımlar 2005-2006 öğretim yılı itibariyle öğretim programlarında önce ilkokul daha sonra da ortaöğretim kademesinde uygulanmaya başlanmıştır. Skolastik dönem, modernizm ve postmodernizm döneminde eğitim sistemlerine yön veren felsefi akımlar, her dönemin kendine özgü insan modelini oluşturmak için farklı hedefler temelinde hareket etmişlerdir. Özellikle skolastik dönemden modernizm dönemine geçişte uygulamada yer bulan eğitim felsefeleri birbirleri ile karşıt zeminde insan modeli yetiştirmişlerdir. Ülkemizde ise İslamiyet öncesi Türk devletlerinde, Osmanlı'da ve nihayet Cumhuriyet dönemi eğitim politikalarına kozmik dünyada üretilen düşünce yapıları egemen olmuş ve bu doğrultuda eğitim politikaları üretilmiştir. Bu yazılanlar ışığında Türk eğitim sisteminde, kavram ve ilke oluşturma çabaları Tanzimat dönemi ile başlamış ve yerel toplum motiflerine uygun sistemsel bir eğitim felsefesi oluşturulamamış olup çağdaşlaşma kavramı ise Batıda üretileni alıp eğitim politikalarıyla bütünleştirme şeklinde bu çaba doğrultusunda arayışların devam ettiği söylenebilir. Oysa her toplum, kendi tarihi birikimini ve olanaklarını kullanarak gereksinimleri doğrultusunda kendi kimliğine uygun eğitim felsefesini geliştirebilmeli ya da şekillendirebilmelidir.

Skolastik dönemde Hristiyanlık dininin savunulması ve ön planda tutulması felsefi düşüncenin ve eğitim etkinliklerinin şekillenmesinde etkili olmuştur. Skolastik yöntemin 1şı̆̆ında ilerlemek, Hristiyanlığın ve kilisenin koyduğu kurallara bağlı kalmak, birlik içinde hareket etmek önem kazanmıştır. Manastır ve kilisedeki eğitimler devam ederken üniversitelerin de kuruluşu Hristiyanlığa özgü felsefenin çok sayıda öğrenci yetiştirilmesi yoluyla kendine özgü bir yapı kurulmasını ve sistemleştirilmesini sağlamıştır. (Cevizci, 2001; Topdemir, 2012). Modernizm Dönemine gelindiğinde okullar, pozitivist düşüncenin de etkisinde kalarak ideolojilerin aktarıldığı, kuralların izinde öğrenci yetiştiren kurumlar olarak görülmüştür. Bilim ve teknoloji alanında yapılan devrimler işletmeye özgü kavram ve uygulamaların eğitime aktarıldığı, eğitim politikalarının merkeziyetçi bir yapı ile yönetildiği nihayetinde kuralların insan gereksinim ve beklentisinden daha ön planda tutulduğu bir anlayış bu dönemin en belirgin özellikleri olarak kendini belirginleştirmiştir (Aslanargun, 2007; Lunenberg, 1998). Postmodern dönemde bilgi anlayışında özgürleşme çabası hakim olmuştur. Bilginin öznelliği, bilginin 
yapılandırılabileceği anlayışı ön plana çıkmıştır. Bu dönemde çoğulculuk anlayışının da egemen olması nedeniyle öğretmen sınıf içinde rehber rolünde yer almıştır. Merkeziyetçi yapının azaltılması amacıyla da öğretmenlerin il içinde görev yerinin değiştirilmesi gibi bazı yetkiler yerel yönetimlere devredilmiştir (Karadağ ve diğ., 2008; Kılıç ve Bayram, 2014; Özdemir, 2014).

\section{Kaynakça}

Akınoğlu, O. (2005). Türkiye'de uygulanan ve değişen eğitim programlarının psikolojik temelleri. Marmara Üniversitesi Atatürk Eğitim Fakültesi Eğitim Bilimleri Dergisi, 22(22), 31- 46. https://dergipark.org.tr/tr/download/articlefile/1743 adresinden erişilmiştir.

Aksoy, İ. (2008). II. Meşrutiyet dönemi eğitim politikası ve Satı Bey. Gazi Türkiyyat, 3(4), 67- 81. https://dergipark.org.tr/tr/pub/gaziturkiyat/issue/6716/90224 adresinden erişilmiştir.

Alabaş, R. (2016). Türk eğitim tarihi dersinin önemi hakkında öğretmen adaylarının görüşleri. Cumhuriyet International Journal of Education, 5(4), 89-102. doi: 10.30703/cije.321417

Altın, H. (2010). Ziya Gökalp'in eğitim tarihimiz açısından önemi. History Studies: International Journal of History, 2(2), 493- 509.

Antalyalı, Ö. L. (2007). Tarihsel süreç içerinde üniversite misyonlarının oluşumu. Süleyman Demirel Üniversitesi Sosyal Bilimler Dergisi, 6(6), 25-40. https://dergipark.org.tr/tr/pub/sbe/issue/23199/247811 adresinden erişilmiştir.

Arslan, M. (2007). Eğitimde yapılandırmacı yaklaşımlar. Ankara Üniversitesi Eğitim Bilimleri Fakültesi Dergisi, 40(1), 41-61. doi: 10.1501/Egifak_0000000150

Arslan, M. (2016). Gaspıralı İsmail Bey'in eğitim reformu ve Usul-u Cedid Gaspıralı İsmail Bey'in yaşam öyküsü ve Türk fikir hayatına etkileri. GAU Journal of Social and Applied Science, 8(1), 8-21. www.researchgate.net/publication/309726890_GASPIRALI_ISMAIL_BEYIN _EGITIM_REFORMU_VE_USULU_CEDID_GASPIRALI_ISMAIL_BEYIN_YASAM_OYKUSU_VE_TURK_ FIKIR_HAYATINA_ETKILERI adresinden erişilmiş̧ir.

Aslanargun, E. (2007). Modern eğitim yönetimi anlayışına yönelik eleştiriler ve postmodern eğitim yönetimi. Kuram ve Uygulamada Eğitim Yönetimi Dergisi, 50(2), 195- 212. https://dergipark.org.tr/tr/pub/kuey/issue/10347/126733 adresinden erişilmiştir.

Aydın, H. (2006). Eleştirel aklın ışı̆̆ında postmodernizm: Temel dayanakları ve eğitim felsefesi. Ĕgitimde Politika Analizleri ve Stratejik Araştırmalar Dergisi, $1(1), 27-48$. 
Baş, G. ve Beyhan, Ö. (2017). Sosyal yapılandırmacı öğrenme ortamı tasarımının öğrenenlerin akademik başarılarına ve derse yönelik tutumlarına etkisi. Mehmet Akif Ersoy Üniversitesi Eğitim Fakültesi Dergisi, 1(41), 137- 162.

Başaran, B. I. (2004). Etkili öğrenme ve çoklu zekâ kuramı: Bir inceleme. Ege Eğitim Dergisi, 5(1), 7-15. https://dergipark.org.tr/tr/pub/egeefd/issue/4920/67308 adresinden erişilmiştir.

Bayar, I. (2001). Ochamlı William'in epistemolojisi. Hacettepe Üniversitesi Edebiyat Fakültesi Dergisi, $\quad 18(1), \quad$ 165-186. https://dergipark.org.tr/tr/pub/huefd/issue/41189/497374 adresinden erişilmiştir.

Bayram, Y. (2007). Postmodernizm (modernizm ötesi). Baykara, 9(5), 37-39. http://turkoloji.cu.edu.tr/YENI\%20TURK\%20EDEBIYATI/yavuz_bayram_po stmodernizm.pdf adresinden erişilmiştir.

Cemaloğlu, N. (2019). Eğitimin pin kodu. Ankara: Pegem Akademi.

Cevizci, A. (2001). Ortaçağ felsefesi tarihi. Bursa: Asa.

Cihan, M. (2010). John Locke ve eğitim. Atatürk Üniversitesi Sosyal Bilimler Enstitüsü $\quad$ Dergisi, $\quad 7(1), \quad 173-\quad 178$. https://dergipark.org.tr/tr/pub/ataunisosbil/issue/2817/37933 adresinden erişilmiş̧ir.

Çağır, M. ve Türk, İ. C. (2017), 1869 Maarif-i Umumiye Nizamnamesi ve Türk eğitim tarihindeki yeri. Avrasya Sosyal ve Ekonomi Araştırmaları Dergisi, 4(11), 6275. https://dergipark.org.tr/tr/pub/asead/issue/52677/694343 adresinden erişilmiştir.

Çakır, O. ve Doğan, M. C. (2017). İlkokul öğretmenlerinin postmodern eğitim anlayışına ilişkin görüşleri. Eğitim Kuram ve Uygulama Araştırmaları Dergisi, 3(01), 38- 52. https://dergipark.org.tr/tr/pub/ekuad/issue/28620/311132 adresinden erişilmiştir.

Çilingir, L. ve Küçükali, R. (2004). Immanuel Kant'ın eğitim anlayışı. Kazım Karabekir Eğitim Fakültesi Dergisi, (10), 81-98. https://dergipark.org.tr/en/download/article-file/31404 adresinden erişilmiştir.

Çüçen, A. K. (2000). Ortaçağ felsefe tarihi. İstanbul: İnkılap.

Çüçen, A. K. (2006). Batı aydınlanmasının düşünsel kökenleri ve eleştirisi [Atatürk'ün Doğumunun 125. Y1lı ve Cumhuriyetimizin 83. Y1lı Özel Sayıs1]. Muğla Üniversitesi Sosyal Bilimler Enstitüsü Dergisi, 25-34. https://dergipark.org.tr/tr/pub/musbed/issue/23528/250685 adresinden erişilmiştir.

Demirel, Ö. (Ed.). (2011). Eğitimde yeni yönelimler. Ankara: Pegem. 
Durdu, Z. (2006). Frankfurt okulunun sosyal bilim anlayışı. Sosyoloji Dergisi, (15), 15-32. https://dergipark.org.tr/tr/pub/sosder/issue/40985/495127 adresinden erişilmiştir.

Ergün, M. (2008). Cumhuriyet dönemi eğitim tarihi. Türkiye Araştırmaları Literatür Dergisi, $\quad 6(12), \quad 321-348$. https://dergipark.org.tr/tr/pub/talid/issue/43479/530662 adresinden erişilmiştir.

Eyyupoğlu, İ. (2017). Köy enstitülerinin kuruluşu ve Pulur köy enstitüsü öğrencilerinden Muammer Genç'in anıları. Atatürk Dergisi, 6(1), 1-21. https://dergipark.org.tr/tr/pub/atauniad/issue/30787/371475 adresinden erişilmiştir.

Gül, E. C. (2016). Postmodern sanrı ve yabancılaşma gerçeği. Toros Üniversitesi Sosyal Bilimler Dergisi, $\quad 3(6), \quad$ 75-107. https://dergipark.org.tr/tr/pub/iisbf/issue/27278/287170 adresinden erişilmiştir.

Güven, M. (2017). Ortaçağ'da şehir ve felsefe ilişkisi üzerine güncel yaklaşımlar. Akademik ve Sosyal Araştırmalar Dergisi, 5(41), 321-328. doi: 10.16992/ASOS.11951

Freire, P. (2017). Ezilenlerin pedagojisi [Pedagogia do oprimido]. (D. Hattatoğlu, Çev.). İstanbul: Ayrıntı Yayınları. (1982)

Fırat, N. Ş. (2006). Pozitivist yaklaşımın eğitim yönetimi alanına yansıması, alana getirdiği katkı ve sınırlılıkları. Dokuz Eylül Üniversitesi Buca Eğitim Fakültesi Dergisi, (20), 40-51. https://dergipark.org.tr/tr/pub/deubefd/issue/25440/268419 adresinden erişilmiştir.

Goldman, J. (2004). Modernism 1910-1945 image to apocalypse. England: Palgrave Macmillan.

Güçlüol, K. (1985). John Dewey raporundan esintiler. Eğitim ve Bilim Dergisi, 9(53), 4-7. http://egitimvebilim.ted.org.tr/index.php/EB/article/view/5386 adresinden erişilmiştir.

Gökberk, M. (2003). Felsefe tarihi. İstanbul: Remzi.

Guess, R. (1981). The idea of a critical theory Habermas and the Frankfurt school. Cambridge: Cambridge University.

Gümüş, T. T. (2010). Ortaçağ'dan erken modern döneme Batı Avrupa'da eğitim tarihi: Yaklaşımlar. Mersin Üniversitesi Ë̆itim Fakültesi Dergisi, 6(1), 25-40. https://dergipark.org.tr/tr/pub/mersinefd/issue/17373/181416 adresinden erişilmiştir.

Hali, S. ve Rencüzoğulları, S. (2017). İslamiyet öncesi dönemde Türklerde eğitim. 21. Yüzylda Eğitim ve Toplum Dergisi, 6(17), 425-437. https://dergipark.org.tr/tr/pub/egitimvetoplum/issue/35909/402840 adresinden erişilmiştir. 
Hausmann, G. V. (1957). Genç Hegel'de eğitim düşüncesi [Die erziehungsidee beim jungen Hegel]. (N. Hızır, Çev.). Ankara Üniversitesi Dil ve Tarih-Coğrafya Fakültesi Dergisi, 15(3), 201-207. http://www.dtcfdergisi.ankara.edu.tr/index.php/dtcf/article/view/4195/0 adresinden erişilmiştir.

Kabadayı, T. (2001). Nietzsche ve eğitim. Hacettepe Üniversitesi Eğitim Fakültesi Dergisi, (20), 180-184. https://dergipark.org.tr/tr/pub/hunefd/issue/7816/102673 adresinden erişilmiştir.

Karadağ, E., Deniz, S., Korkmaz, T. ve Deniz, S. (2008). Yapılandırmacı öğrenme yaklaşımı: Sınıf öğretmenleri görüşleri kapsamında bir araştırma. Uludağ Üniversitesi Ë̆itim Fakültesi Dergisi, 12(2), 383-402. https://dergipark.org.tr/tr/pub/uefad/issue/16688/173423 adresinden erişilmiştir.

Karataş, S. (2003). Osmanlı eğitim sisteminde batılılaşma. Afyon Kocatepe Üniversitesi Sosyal Bilimler Dergisi, 5(1), 231-242. http://aves.akdeniz.edu.tr/skaratas/yayinlar adresinden erişilmiştir.

Keha, M. K. (2016). Modern felsefenin öncüleri: Descartes ve Bacon'da yöntem sorunu. Atatürk Üniversitesi Edebiyat Fakültesi Sosyal Bilimler Dergisi, (56), 117-132. https://dergipark.org.tr/tr/pub/ataunisosbd/issue/35455/392937 adresinden erişilmiştir.

Kılıç, K. L. ve Bayram, B. (2014). Postmodernizm ve eğitim. Uluslararası Türkçe Edebiyat Kültür Eğitim Dergisi, 3(1), 368-376. doi: 10.7884/teke.261

Kırılmaz, H. ve Ayparçası, F. (2016). Modernizm ve postmodernizm süreçlerinin tüketim kültürüne yansımaları. Insan ve İnsan, 3(8), 32-38. doi: 10.29224/insanveinsan.280014

Kocabaş, A. (2008). Türk Eğitim sisteminin felsefi temelleri: Değerlendirme, tartışma ve cevap yazıları. Toplum ve Demokrasi, 2(3), 203-212. https://dergipark.org.tr/tr/download/article-file/211048 adresinden erişilmiştir.

Köroğlu, C. Z. ve Köroğlu, M. A. (2016). Bilim kavramının gelişimi ve günümüz sosyal bilimleri üzerine. Pamukkale Üniversitesi Sosyal Bilimler Dergisi, (25), 1-15. https://dergipark.org.tr/tr/pub/pausbed/issue/34751/384330 adresinden erişilmiştir.

Kurt, M. (2006). Postmodern education: Critical and border pedagogies. Cypriot Journal of Education Sciences, 1(2), 84-93.

Küçük, S. (2015). Ortaçağ'da Hristiyanlık ve İslam dinlerinin felsefe ve bilim üzerine etkileri. Alevilik-Bektaşilik Araştırmaları Dergisi, 11, 43-64. doi: 10.24082/abked.2015.11.002

Lunenberg, F. C. (1998). Constructivism and technology: Instructional designs for successful education reform. Journal of Instructional Psychology, 25(2), 75-81. 
Macit, M. H. ve İplikci, A. (2017). Tarih felsefesi. Ankara: Pegem.

Mengüş̧oğlu, T. (2012). Fenomenolojinin felsefesi. Felsefe Arkivi, (1), 47-74. https://dergipark.org.tr/tr/pub/iufad/issue/1302/15361 adresinden erişilmiş̧ir.

Milli Eğitim Bakanlığı. (2020). 2023 eğitim vizyonu. http://2023vizyonu.meb.gov.tr/ adresinden erişilmiştir.

Öktem, Ü. (2005). Fenomenoloji ve Edmund Husserl'de apaçıklık problemi. Ankara Üniversitesi Dil ve Tarih-Coğrafya Fakültesi Dergisi, 45(1), 27-55. http://www.dtcfdergisi.ankara.edu.tr/index.php/dtcf/article/view/1126 adresinden erişilmiştir.

Özdemir, M. (2008). Eğitim yönetiminde yerelleşme siyasaları. Amme İdaresi Dergisi, 41(3), 153-158.

Özdemir, İ. (2014). Postmodern düşüncenin Türkiye'de eğitim sistemine yansımaları. Milli Ĕgitim Dergisi, 4 44(204), https://dergipark.org.tr/tr/pub/milliegitim/issue/36160/406463 adresinden erişilmiştir.

Pereira, J. (2006). Suárez between scholasticism and modernity. Milwaukee Wisconsin: Marquette University.

Rescher, N. (2005). Scholastic meditations. In J. P. Dougherty (Ed), Studies in philosophy and the history of philosophy (pp. 1-167). Washington, D. C: The Catholic University of America.

Rousseau, J. J. (2009). Emile [Emile ou de l'education]. (Y. Avunç, Çev.). İstanbul: Türkiye İş Bankası Yayınları. (1911)

Sebetci, H. (2016). 11 ve 12. yüzyıllarda Ortaçă̆ Avrupası'nın eğitime genel yaklaşımı. Sosyal ve Kültürel Araştırmalar Dergisi, 2(3), 91-105. https://dergipark.org.tr/tr/pub/skad/issue/21060/226767 adresinden erişilmiştir.

Secada, J. (2004). Cartesian metaphysics: The late scholastic origins of modern philosophy. United Kingdom: Cambridge Press.

Seferoğlu, S. S. ve Akbıyık, C. (2006). Eleştirel düşünme ve öğretimi. Hacettepe Üniversitesi Ĕgitim Fakültesi Dergisi, 30(30), 193-200. https://dergipark.org.tr/tr/pub/hunefd/issue/7806/102380 adresinden erişilmiştir.

Smelter, N. J., and Baltes, P. B. (Ed.). (2001). International encyclopedia of the social and behavioral sciences. USA: Pergamon.

Sönmez, V. (2015). Eğitim felsefesi. Ankara: Anı.

Şaylan, G. (2016). Postmodernizm. Ankara: İmge. 
Şentürk, İ. ve Turan, S. (2012). Foucault'un iktidar analizi bağlamında eğitim yönetimine ilişkin bir değerlendirme. Kuram ve Uygulamada Eğitim Yönetimi Dergisi, 18(2), 243-272. https://dergipark.org.tr/tr/pub/kuey/issue/10324/126586 adresinden erişilmiştir.

Topdemir, H. G. (2012, Ocak). Ortaçă̆ uygarlıklarında bilgi ve bilim. Bilim ve Teknik, https://e-dergi.tubitak.gov.tr/edergi/yazi.pdf;jsessionid=8r9kfwuORGe3mzD4Be8+9Hx?dergiKodu=4\&cilt $=45 \&$ sayi $=758 \&$ sayfa $=72 \&$ yaziid $=32691$ adresinden erişilmiştir.

Uslu-Çetin, O. ve Özdemir, M. (2019). Postmodernizmin eğitim yönetimindeki izlerinin Fenwick English üzerinden değerlendirilmesi. Ankara Üniversitesi Eğitim Bilimleri Fakültesi Dergisi, 52(2), 547-575. doi: 10.30964/auebfd.511559

Yayla, A. (2005). Kant'ın ahlak eğitimi anlayışı. Ankara Üniversitesi Ĕgitim Bilimleri Fakültesi Dergisi, 38(1), 73-86. doi: 10.1501/Egifak_0000000106

\section{Etik Kurul Kararı}

$\mathrm{Bu}$ araştırma, derleme makalesi türünde olduğu için etik kurul kararı zorunluluğu taşımamaktadır. 


\title{
The Philosophy of the Cosmic Structure in the Turkish Education System ${ }^{1}$
}

\begin{tabular}{cccc}
\hline ARTICLE TYPE & Received Date & Accepted Date & Published Date \\
Review Article & 04.20 .2020 & 04.24 .2021 & 05.31 .2021 \\
\hline & Nuray Özge Sağbaş iD ${ }^{2}$ & \\
Ministry of National Education & \\
Murat Özdemir iD & \\
Hacettepe University
\end{tabular}

\begin{abstract}
The aim of this study is to describe the concepts, principles and thought systems that affect and direct the structure of the Turkish Education System within the historical development process. For this purpose; the scholastic period, the theories of philosophers who produced knowledge within the scope of the modernism and postmodernism processes and the reflections of the philosophical aspect of these theories to the Turkish education system were researched. For that purpose, philosophers, who were influential in the periods of scholastic, modernism and postmodernism, their ideas and philosophical structures which were valid in that period how to shape the education system were explained by using the concept of the cosmic structure. Therefore, philosophical views that the philosophers in the periods advocated initially, the direction to which movement philosophical views lead, and ultimately the developments in the education system of our country are included. Scholastic period, the theological world view that marked in the period; changes in the social structure of modernism, economic, cultural and political changes; postmodernism, on the other hand, was studied on the basis of the movements that marked the philosophy of education in an effort to understand the other under the influence of the globalization process. It has concluded that the cosmic structure wind that started to blow in the west under these study titles influenced and shaped the educational philosophy and movements in our country.
\end{abstract}

Keywords: Scholastic philosophy, modernism, postmodernism, educational philosophy movements.

Ethics committee approval: Since this research is in the form of a review article, it does not require an ethics committee decision.

${ }^{1}$ Presented as a report at the 6th International Chaos, Complexity and Leadership Symposium.

${ }^{2}$ Corresponding Author: Dr., Office of The Private Secretary, E-mail: nurayozgesagbas@ hotmail.com, https://orcid.org/0000-0003-2630-8620

${ }^{3}$ Prof. Dr., Faculty of Education, Department of Educational Sciences, Division of Educational Administration, E-mail: mrtozdem@ gmail.com, https://orcid.org/0000-0002-1166-6831 


\section{Purpose and Significance}

Philosophical movements shaping the education management, when evaluated in the scope of historiosophy, one point of view from upper frets to the history of the world and Turkey, on the other hand, it requires to study how humanity create a bridge philosophically to the future from past manufacturing (Macit and İplikci, 2017). Scholasticism, also called medieval philosophy, formed the basis of religious teachings' views of the world and the understanding of dominant philosophy. In this period, philosophical studies found a soul in line with the principles and theories of the church and had a stable period. Modernism that stands out from the traditional social life by breaking its shell; The Renaissance, which is called the Enlightenment Movement and covers the innovations in literature, fine arts and scientific fields that started Europe under the influence of Europe, includes the Reform movement in which Martin Luther contributed to the rapid spread of the church with the ideas produced by opposing the religious understanding. Although the Enlightenment philosophy was replaced by the French Revolution, which contributed to the establishment of new nation-states and the re-centering of mind, the Industrial Revolution which started simultaneously with the French Revolution included a longer term (Kırılmaz and Ayparçası, 2016). Postmodernism, which started to show its effect in the United States since 1950s, found its place in the literature as an expression of its break from the process of modernism and the transition beyond modernism and approached clarity with skepticism based on processing new forms of expression that are missing in the process of modernism (Şaylan, 2016).

Philosophical movements in education have shaped the educational goals and objectives desired by influencing the policies in the education system. Approaches that are sometimes teacher and subject-centered have shown themselves as failures in national and international exams in recent years, and a formation has been entered into the need to include student-centered education in education. The basis of these philosophical currents, which includes the restructuring process and the effects of postmodernism, is based on the Ancient Age and Greek philosophy. Understanding the structure that shapes the future is through understanding the past. Therefore, in this study, it has become necessary to analyze how views affecting the periods affect the education system.

In this study, it is aimed to describe how the philosophical structure that guides the Turkish education system has evolved in the historical process. For that purpose, philosophers, who were influential in the periods of scholastic, modernism and postmodernism, their ideas and philosophical structures which were valid in that period the way they shaped the education system were explained by using the concept of the cosmic structure. Therefore, philosophical views that the philosophers in the periods advocated initially, the direction to which movement philosophical views lead, and ultimately the developments in the education system of our country are included. The study was limited to the scholastic period of the Middle Ages and again with this period, the views of philosophers who guided modernism and postmodernism with their effects on education. In this context, the field was literally 
scanned and the philosophers, who left a deep mark on the philosophy of education, were examined in detail.

This review article is prepared by depending on a national and international literature review on scholastic philosophy, modernism and postmodernism. For this purpose, the related literature including thesis, books and articles has been reviewed. Professors working on philosophy in this field were contacted and their opinions were received. ULAKBIM TR DIRECTORY Committee has not been uploaded since the Ethics Committee Approval was not requested for review articles according to the magazine evaluation criteria for 2020.

The philosophical structure formed as a result of the act of thinking in the historical process has guided the education system in terms of the movements placed on a different basis according to the periods. In particular; idealism, realism, pragmatism, positivism-based philosophies have shown their effect on educational processes. In this study, the cosmic structure that directs the Turkish education system has been examined on the basis of philosophers and philosophical movements. For this purpose, the philosophical structure that guides the Turkish education system has been examined in three periods: scholastic period, modernism and postmodernism, and in this direction, the philosophers, their philosophies and the effects of philosophical movements related to the educational system developing in each period are described.

According to the idealism movement showing its effect in the scholastic period that constitutes the first part of the study, education is considered as an effort of reaching to God, while realism (literalism) considers it as a means of adaptation of the cultural accumulation from the past to individuals by transmitting to the individuals. In this respect, idealism has been the source of eclecticist, conservative and rulemaking education approach to the scholastic way of thinking guiding Medieval education philosophy. Famous philosophers of this period, on the other hand, produced thought structures based on the philosophical understanding of this period, and the ideas developed in this direction also directed the understanding of education. The education system of this period, which has a conservative identity in terms of transferring knowledge and existing culture, has fulfilled the oldest duty of education. In the second part of the study, current pragmatism (utilitarianism), which is identified with the period of modernism, interpreted education as a reshaping of human behavior through experiences, while naturalism (naturalism) developed a perspective towards education in order to increase the maturation levels of individuals naturally and display this maturing behavior. It showed the world a perspective on physical reality. The progressive educational philosophy influencing the period of modernism has taken its source from pragmatism. Approaches developed with the re-constructionism flow in our country with the postmodernism period started to be applied firstly in primary education and then in secondary education by 2005-2006 academic year. 


\section{Discussion and Conclusions}

Considering that education is the art of ensuring to act by guiding the behavior of individuals in line with the determined goals, the meanings attributed to education also change in terms of philosophical views. Philosophy is an act of thinking. It contributes to the direction of the policies produced in the education system by producing activities on the basis of intellectual and implementation. Philosophical ways of thinking not only provide a different perspective to the field of corporate governance and but also guide the education system. In this context, in the scholastic era, permanentism and essentialism, which took their foundation from the philosophies of idealism and realism, found itself in a traditional understanding where the human mind is empty and it should be developed and the discipline is based on. Considering the Turkish education system, the existence of a nomadic life in the first Turkish states has shaped education in the direction of survival efforts. In the future, clergymen assumed the responsibility of educational activities and places of worship became places of education. The madrasahs, especially opened during the Great Seljuk State and the Ottoman State, were the places where education was carried out as a planned action. Also in these institutions, the educational philosophy of the scholastic era was effective and every word of Islamic scholars was accepted beyond question within this rote-learning based education system. With the declaration of the republic in the Turkish education system, it is possible to see the effects of the modernism period in the reconstruction of the new Turkish state. The positivist practices that influenced this period in the cosmic structure have shown themselves in the practices of restructuring the education system in madrasahs, uniting education institutions under one roof and establishing a ministry responsible for educational affairs, establishing universities and opening village institutes. Postmodernism; the questioning of the modern, the structuring of the information based on the prior knowledge of the student, the subjectivity of the information, the critical perspective, the student's being active in the learning process, the teacher's involvement as a guide away from the authority in the educational environment, the prevalence of multiplism understanding has influenced the education system and shaped the educational practices in terms of content and style all over the world.

Philosophical movements guiding education systems in the scholastic period, modernism and postmodernism period have acted on the basis of different goals to create a unique human model of each period. Educational philosophies, which were found in practice especially in the transition from the scholastic period to the period of modernism, have raised a human model on opposite grounds. In our country in the pre-Islamic Turkish states, thought structures produced in the cosmic world in the Ottoman and finally in the Republican era, education policies have been dominated and education policies have been produced in this direction. In the light of these writings, the efforts to create concepts and principles in the Turkish education system started with the Tanzimat period and a systematic educational philosophy in accordance with the local community motifs could not be created, and the concept of modernisation, on the other hand, can be said that the pursuits continue in the direction 
of this effort in the form of taking produced in the West and integrating it into education policies. However, every society should be able to develop or shape its educational philosophy in line with its own needs in line with its needs by using its own historical knowledge and opportunities.

\section{Ethics Committee Decision}

Since this research is in the form of a review article, it does not require an ethics committee decision. 